\title{
LITTERFALL PRODUCTION OF OAK FORESTS IN NORTHWEST TUNISIA
}

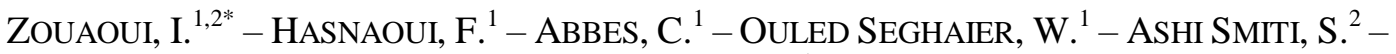 \\ HASNAOUI, B. ${ }^{1}$ \\ ${ }^{1}$ Sylvo Pastoral Institute of Tabarka, University of Jendouba (ISPT) \\ BP 345, 8110 Tabarka, Tunisia \\ ${ }^{2}$ Faculty of Sciences of Tunis, Biology Department, University of Tunis El Manar \\ 2092 Tunis, Tunisia \\ *Corresponding author \\ e-mail: zouaoui.ikbel@gmail.com \\ (Received 22 $2^{\text {nd }}$ Jan 2018; accepted $1^{\text {st }}$ May 2018)
}

\begin{abstract}
Litterfall is considered a key process in determining the carbon and nutrient cycle of the forest ecosystems, and in controlling the main respiration substrates on the forest floor. Litterfall and its seasonal changes were measured monthly for one year, in two sites and three stands of oak forests in Northwest Tunisia. The results show that the total annual litterfall varied significantly according to forest types $(\mathrm{P}<0.01)$ in the range of 7.71-9.89 $\mathrm{t} \mathrm{ha}^{-1} \mathrm{yr}^{-1}$. Litterfall of Quercus suber, Quercus canariensis and mixed stand occur mostly in autumn, winter, spring and summer seasons, respectively. An annual decay coefficient is calculated from litter accumulation data, which varies according to the site and the stand. The decomposition rate is more pronounced in the Quercus canariensis stand, followed by the mixed stand and a slow decomposition in Quercus suber stand.
\end{abstract}

Keywords: forest ecosystem, Quercus canariensis, Quercus suber, decomposition, annual decay coefficient

\section{Introduction}

In the biogeochemical cycle of organic matter and mineral elements, litterfall plays an important part in the relations of soil, vegetation and surrounding environment, constituting one of the essential ecological phenomena in the wooded ecosystems (Vitousek et al., 1995).

The environmental signals activate a series of events leading to the fall of the leaves. The fallen leaves on the soil degraded by the microorganisms allow the recycling of the constituents of the plant material, which are uptaken again by the tree.

The fall of the leaves is not considered as a great loss for the tree because their metabolism is slowed down due to ceased photosynthesis and their constituents are recycled and reused.

Litter dynamics play an important part in the return of nutrients to the forest soil. It is considered an important component in the accumulation of soil organic matter (SOM). It is also one of the major inputs of $\mathrm{C}$ to the soil and an important $\mathrm{C}$ source for SOM (Sayer, 2006). Therefore, litterfall is a key parameter in measuring and predicting soil C sequestration (Liski et al., 2005) and one of the most important variables in the global C cycle (Janssens et al., 2003). The litterfall is characterized by a regular rate from one year to another.

The estimation of the foliar proportion of litter is, however, directly tributary of the other components of the litter whose production is rather variable from one year to 
another because it depends on events which occur with irregular time intervals. Such factors are likely to vary the annual litterfall (Ben Yahia et al., 2016).

The fall of the leaves is considered a very important periodic event in these forests. It represents approximately 65\% of the total litterfall (Vogt et al., 1986) and it contributes to the mobilization of the organic matter. The litterfall is influenced by climate variability and latitude. Berg and Meentmeyer (2001) observed that litterfall is positively correlated with annual evapotranspiration or other climatic indices including average air temperature. Litterfall decreases with the increase in latitude (Bray and Gorham, 1964).

In Tunisia, few studies have been made on the leaf fall and decomposition of organic matter in forests. In this context, the aim of our study is to analyse the seasonal variation of litterfall in Quercus canariensis and Quercus suber forest in Northwest Tunisia and to estimate the decay coefficient from the litter stock.

\section{Materials and methods}

\section{Study area}

The study was carried out in a natural oak forest site in Northwest Tunisia, the site of Khroufa $\left(36^{\circ} 55.5^{\prime} \mathrm{N}\right.$; $\left.08^{\circ} 56^{\prime} \mathrm{E}\right)$ and the site of Ain Zena $\left(36^{\circ} 46.98^{\prime} \mathrm{N} ; 8^{\circ} 43.79 \mathrm{E}\right)$. These sites belong to the forest subdivision of Tabarka and Ain Draham, respectively (Fig. 1).

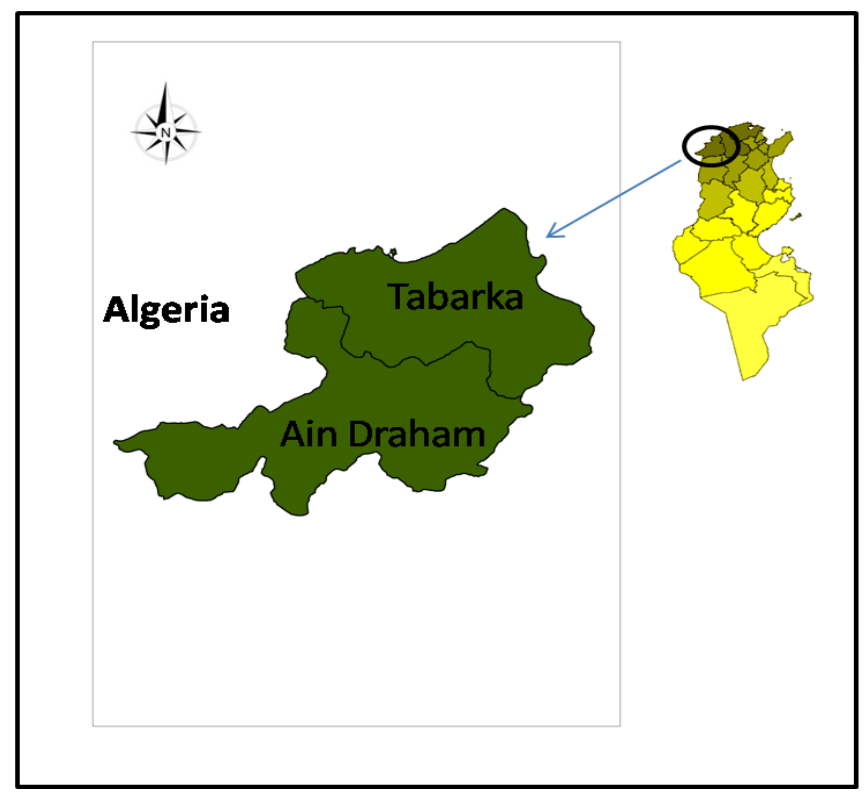

Figure 1. Study area in Northwest Tunisia

The climate of Khroufa forest is characterized by mild winters while the climate of Ain Zena forest is described as having temperate winter with snowy precipitations (Fig. 2).

Each of the two study sites consists of three stands. The dominant species in stand 1, 2 and 3 are Quercus canariensis (QC), Quercus suber $(Q S)$ and Quercus canariensis and Quercus suber (mixed), respectively (Fig. 3). A detailed description of the sites is indicated in Table 1. 

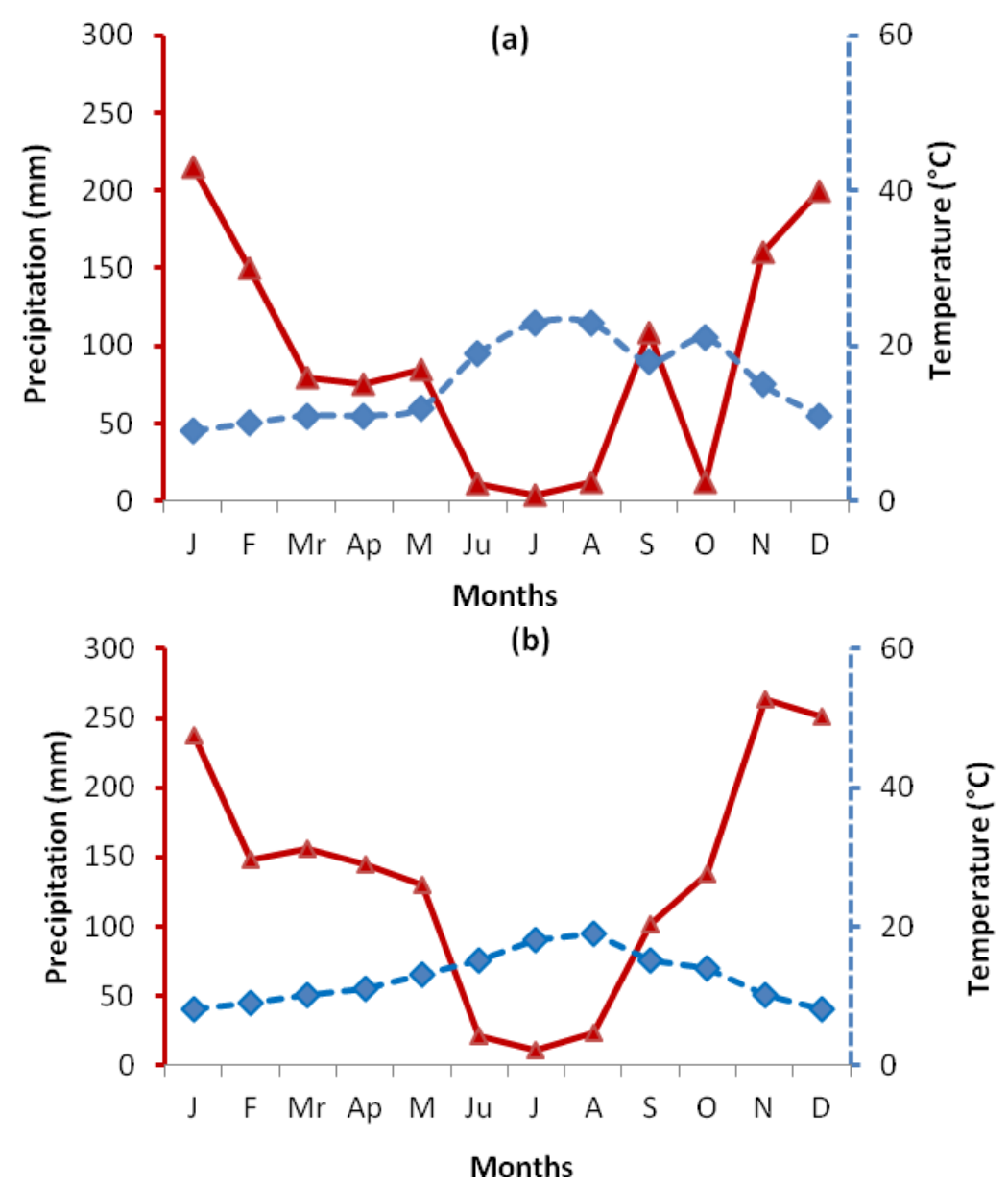

Figure 2. Ombrothermic diagram of Bagnouls and Gaussen $(P=2 T)$ for the year 2011 for the two sites (a) Khroufa and (b) Ain Zena

Table 1. Characteristics of the study sites

\begin{tabular}{|c|c|c|c|c|c|c|}
\hline Sites & \multicolumn{3}{|c|}{ Khroufa } & \multicolumn{3}{|c|}{ Ain Zena } \\
\hline Stands & 1 & 2 & 3 & 1 & 2 & 3 \\
\hline Coordinates & $\begin{array}{l}36^{\circ} 55^{\prime} 27.0^{\prime \prime} \mathrm{N} \\
08^{\circ} 57^{\prime} 03.7^{\prime}, \mathrm{E}\end{array}$ & $\begin{array}{l}36^{\circ} 55^{\prime} 53.8^{\prime \prime} \mathrm{N} \\
08^{\circ} 56^{\prime} 37.7^{\prime \prime} \mathrm{E}\end{array}$ & $\begin{array}{l}36^{\circ} 55^{\prime} 35.4^{\prime \prime} \mathrm{N} \\
08^{\circ} 56^{\prime} 26.6^{\prime \prime} \mathrm{E}\end{array}$ & $\begin{array}{l}36^{\circ} 44^{\prime} 09.4^{\prime \prime} \mathrm{N} \\
08^{\circ} 51^{\prime} 38.1^{\prime \prime} \mathrm{E}\end{array}$ & $\begin{array}{c}36^{\circ} 44^{\prime} 59^{\prime \prime} \mathrm{N} \\
08^{\circ} 52^{\prime} 11.8^{\prime \prime} \mathrm{E}\end{array}$ & $\begin{array}{l}36^{\circ} 44^{\prime} 23.4^{\prime \prime} \mathrm{N} \\
08^{\circ} 52^{\prime} 05.7^{\prime \prime} \mathrm{E}\end{array}$ \\
\hline $\begin{array}{l}\text { Altitude } \\
\text { (m) }\end{array}$ & $530-590$ & $430-465$ & $500-530$ & $850-870$ & $800-820$ & $820-845$ \\
\hline Soil type & $\begin{array}{l}\text { Cambisols } \\
\text { humic }\end{array}$ & $\begin{array}{l}\text { Cambisols } \\
\text { humic }\end{array}$ & $\begin{array}{l}\text { Cambisols } \\
\text { humic }\end{array}$ & Luvisols & Luvisols & Luvisols \\
\hline $\begin{array}{c}\text { Natural } \\
\text { vegetation }\end{array}$ & Q. canariensis & Q. suber & $\begin{array}{c}Q . \text { canariensis } \\
+Q . \text { suber }\end{array}$ & Q. canariensis & Q. suber & $\begin{array}{l}\text { Q. canariensis } \\
+ \text { Q. suber }\end{array}$ \\
\hline $\begin{array}{c}\text { Plant } \\
\text { associations }\end{array}$ & $\begin{array}{c}\text { Erica } \\
\text { arborea, } \\
\text { Arbutus unedo }\end{array}$ & $\begin{array}{c}\text { Erica arborea, } \\
\text { Myrtus } \\
\text { communis, } \\
\text { Pistacia } \\
\text { lentiscus, } \\
\text { Phillyrea } \\
\text { angustifolia, } \\
\text { Smilax aspera }\end{array}$ & \begin{tabular}{|} 
Erica arborea, \\
Myrtus \\
communis, \\
Pistacia \\
lentiscus
\end{tabular} & $\begin{array}{l}\text { Erica arborea, } \\
\text { Arbutus unedo }\end{array}$ & \begin{tabular}{|c|} 
Erica \\
arborea, \\
Myrtus \\
communis, \\
Pistacia \\
lentiscus, \\
Phillyrea \\
angustifolia, \\
Smilax aspera
\end{tabular} & $\begin{array}{l}\text { Erica } \\
\text { arborea, } \\
\text { Myrtus } \\
\text { communis, } \\
\text { Pistacia } \\
\text { lentiscus }\end{array}$ \\
\hline
\end{tabular}



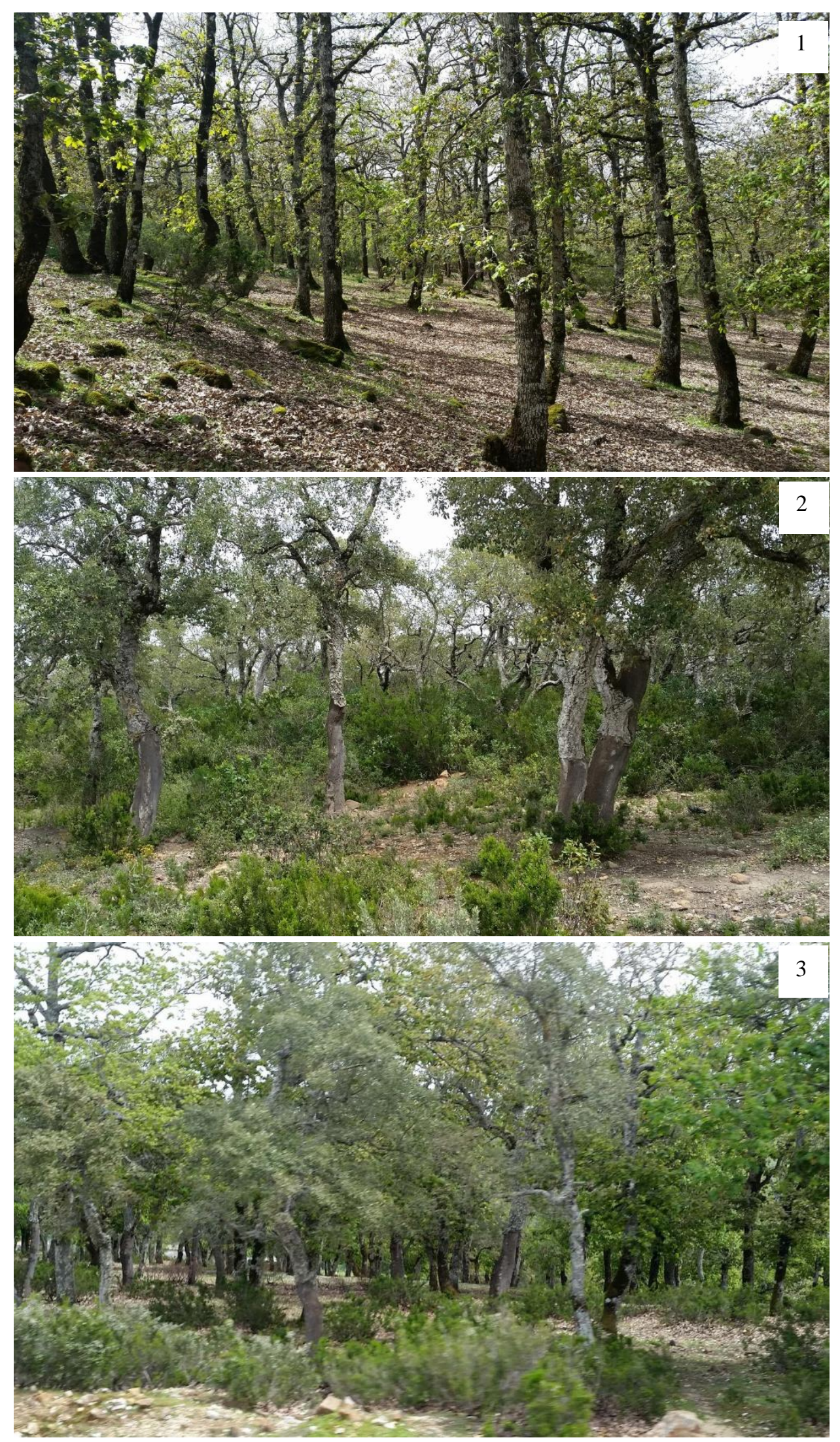

Figure 3. Photos of the different stands studied (1, 2 and 3) 
Quercus suber and Quercus canariensis are important forest species in the Mediterranean region, specifically in Tunisia. They cover 69.870 ha and 6614 ha, respectively

\section{Litterfall collection}

Litterfall was collected monthly throughout a year (from June 2011 to May 2012) for two species (Quercus Canariensis and Quercus Suber) at all sites and stands.

Five plots are established at each stand to measure the litterfall. Five litter traps in each plot ( $1 \mathrm{~m}^{2}$ collecting surface) were installed and located randomly at each plot.

The samples were collected from the five traps and transported to the laboratory, where they were dried at $75{ }^{\circ} \mathrm{C}$ for $48 \mathrm{~h}$, and weighed each month throughout a whole year. The samples were sorted into four components: leaves, twigs, fruits and flowers. Twigs with a diameter of more than $2 \mathrm{~cm}$ were discarded.

After calculating for each plot the litter quantity per litter trap and per year for each fraction, an average value per plot were used to extrapolate litterfall per hectare and per year.

Data analysis was performed using SAS software: Statistical significance of differences between means of different variables were determined by the Student Newman Keuls (SNK) test using a significance threshold of 5\%.

\section{Results}

The litterfall of the two species in the two study sites was estimated. The results show that the dynamics of the litterfall differ significantly with time, sites and stand (Table 2). In the pure Quercus canariensis stand, we noted that the litterfall is highly important during the months of January, February and March.

We noticed that the fall of the leaves and twigs in the pure Quercus canariensis stands in the Khroufa and Ain zena sites are important in winter season (Fig. 4).

Table 2. Variance analysis of the different fractions of the litterfall. Correlation is significant at the 0.05, 0.01 and 0.001 level. $(* P<0.05$, $* * P<0.01$, ***P $<0.001)$

\begin{tabular}{c|c|c|c|c|c}
\hline Variables & Leaves & Twigs & Flowers & Fruits & Total litterfall \\
\hline Sites & 0.43 & $22.09 * * *$ & 0.71 & $54.97 * * *$ & 2.31 \\
Stands & $17.20 * * *$ & $3.41 *$ & $33.94 * * *$ & $16.51 * * *$ & $8.86 * *$ \\
Times & $27.67 * * *$ & $8.42 * * *$ & $10.94 * * *$ & $9.03 * * *$ & $22.87 * * *$ \\
\hline
\end{tabular}

We observed in the two sites that in the pure Quercus suber stand, the highest number of falling leaves was observed during May and June.

At Khroufa's site, the highest number of falling twigs is in June, November and January, whereas it is higher in the summer at Ain Zena's site. The maximum number of leaves dropped in the mixed Quercus canariensis and Quercus suber stands, is in May, January and March in Khroufa, while in Ain zena stands, the highest number of leaves fallen occur from May to July.

The fall of the twigs is intense during winter and summer season in Khroufa and Ain Zena, respectively (Fig. 4). 
Leaf litter contributes to total litterfall, substantially. The percents of leaf litter vary slightly among forest types in a range of $77.3-85 \%$, followed by twigs.

Regarding fruits and flowers (mentioned as other in Fig. 4), there is a significant difference among stands and times $(\mathrm{P}<0.001)$, it is observed that the rates are very low in the two sites and stands. The fall of flowers generally occurs during summer months.

For fruits, the values found are low, especially, in Ain Zena stand; this is probably due to the cattle action in this station.

Khroufa

(a)
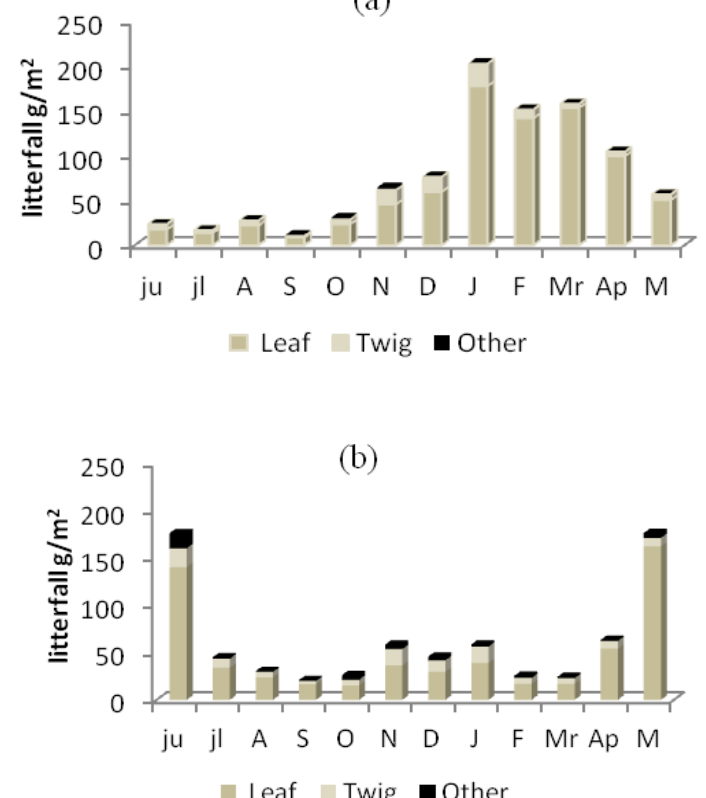

(c)

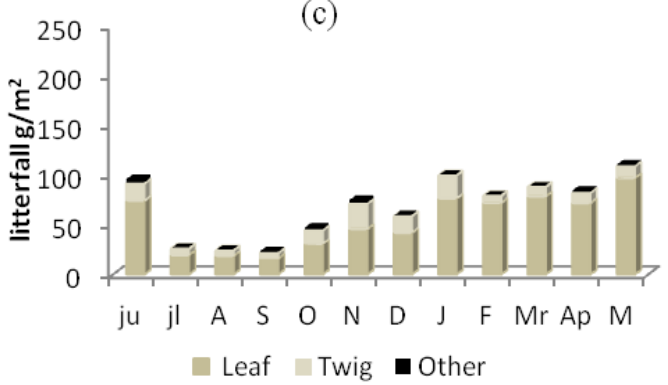

Ain zena

(a)

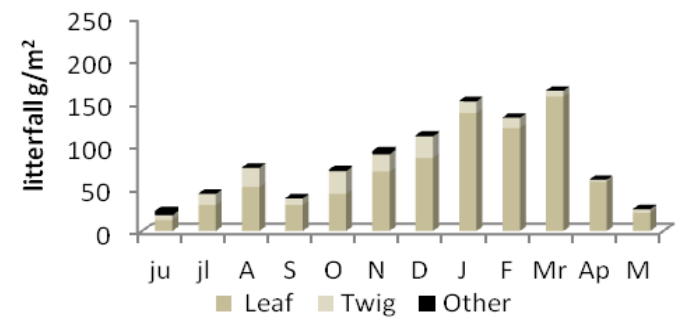

(b)

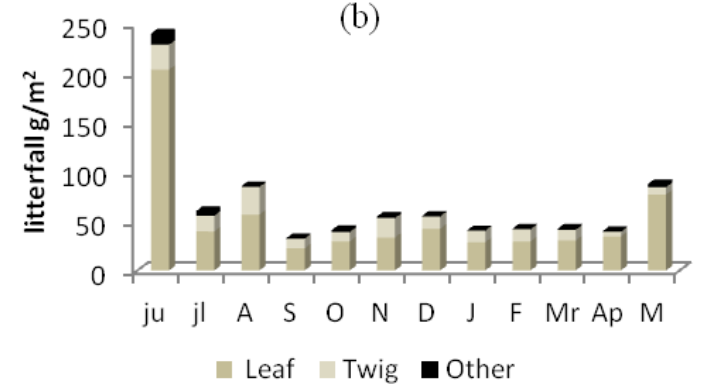

(c)

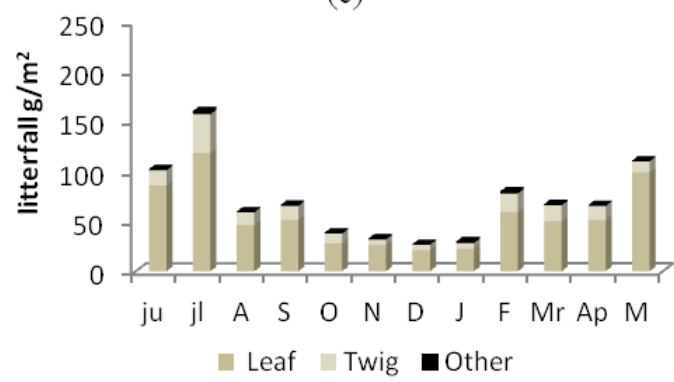

Figure 4. Monthly variation of litterfall in (a) stand 1, (b) stand 2 and (c) stand 3 in Khroufa and Ain Zena sites in northwestern Tunisia

The total litterfall is the most pronounced in the pure Quercus canariensis stand, it is on the order of $9.33 \mathrm{t} \mathrm{ha}^{-1} \mathrm{yr}^{-1}$ and $9.89 \mathrm{t} \mathrm{ha}^{-1} \mathrm{yr}^{-1}$ respectively at Khroufa and Ain Zena sites, moderate in the mixed stand (8.18 and $\left.8.45 \mathrm{t} \mathrm{ha}^{-1} \mathrm{yr}^{-1}\right)$ and low in Quercus suber stand (7.71 and $\left.8.26 \mathrm{tha}^{-1} \mathrm{yr}^{-1}\right)$ (Table 3). 


\section{Litter decomposition rate}

Mass balance techniques are used to estimate litter decomposition for the whole ecosystem. The mass balance for the aboveground litter decomposition, suggests that annual litter decomposition should equal the annual input of fresh litter as long as the mass of stock litter stored in the ecosystem remains constant (Olson, 1963; Schlesinger, 1997).

The coefficient $k=\frac{A}{L}$ (for which $\mathrm{A}=$ annual litterfall and $\mathrm{L}=$ litter stock) can be used to estimate the percentage of litter decomposed by year. Thus, it is possible to obtain the necessary time for the litter to disappear to $100 \%$ (in the absence of input).

The results obtained (Table 3) highlight that the decomposition rate is higher in Khroufa site than Ain Zena. Similarly, the decomposition rate is more pronounced in Quercus canariensis stand; this rate reached $99 \% \mathrm{yr}^{-1}$ at $\mathrm{Khroufa}^{-1}$ and $81 \% \mathrm{yr}^{-1}$ at Ain Zena sites, followed by the mixed stand $\left(90.1 \% \mathrm{yr}^{-1}\right.$ and $\left.75 \% \mathrm{yr}^{-1}\right)$ and, finally, a slow decomposition in Quercus suber stand $75 \% \mathrm{yr}^{-1}$ and $\left.67 \% \mathrm{yr}^{-1}\right)$.

Table 3. Annual litterfall, litter decomposition rate $(k)$ and time of $100 \%$ litter decomposition for the different sites and stands

\begin{tabular}{c|c|c|c|c}
\hline Sites & Stands & $\begin{array}{c}\text { Annual litterfall } \\
\left(\mathbf{t ~ h a}^{-\mathbf{1}} \mathbf{y r} \mathbf{r}^{-1}\right)\end{array}$ & $\mathbf{k}\left(\boldsymbol{\%} \mathbf{~ \mathbf { ~ r }} \mathbf{- 1}^{\mathbf{1}}\right)$ & $\begin{array}{c}\text { Time of 100\% litter } \\
\mathbf{d e c o m p o s i t i o n}(\mathbf{d a y s})\end{array}$ \\
\hline \multirow{3}{*}{ Khroufa } & QC & 9.33 & 99 & 369 \\
& Mixed & 6.45 & 90.1 & 405 \\
& QS & 6.06 & 75 & 487 \\
\hline \multirow{3}{*}{ Ain Zena } & QC & 9.89 & 81 & 451 \\
& Mixed & 8.45 & 75 & 487 \\
& QS & 8.26 & 67 & 545 \\
\hline
\end{tabular}

\section{Discussion}

The litter input of the present study (7.71 to $9.89 \mathrm{t} \mathrm{ha}^{-1} \mathrm{yr}^{-1}$ ) in the forest stands is higher than the values of $5 \mathrm{t} \mathrm{ha}^{-1} \mathrm{yr}^{-1}$ recorded by Selmi (1985); and other studies carried out on the oak forests of the Mediterranean Basin.

The litterfall of the Quercus suber is about $5.6 \mathrm{t} \mathrm{ha}^{-1} \mathrm{yr}^{-1}$ in Portugal and Spain (Sa et al., 2001; Caritat et al., 2006). In May and June, the peak of the leaf fall changes depending on the year (Bellot et al., 1992; Caritat et al., 1996; Martin et al., 1996). The fall of leaves at the end of spring may be due to an adaptation to the hydric deficit that can occur during the dry season (July and August), in the Mediterranean areas (Escudero et al., 1987).

However, the estimation of the proportion of leaf litter is directly dependent on other components of litter (Ben Yahia et al., 2016). The input is variable from one year to another because it depends on events that occur at irregular intervals. Therefore, some factors are likely to vary the annual litter production. The high values found in our study are probably due to higher temperatures and lower precipitation.

Dendroclimatological studies in Tunisia and Morocco (Aloui, 1982; Raouane, 1985) have shown that Quercus canariensis has a greater sensitivity to precipitation than to 
temperatures. But on the other hand, it is indifferent to the physico-chemical nature of the soil.

Our study shows that the fall of the twigs takes place in winter for Quercus canariensis stand and at the beginning of summer and winter for the two others stands. This may vary from one study to another since the twig fall depends significantly on wind and storms. According to Caritat et al. (2006), the fall period takes place mostly at the beginning of springtime and at the end of autumn, and it varies a lot depending on the year as observed for the same species in Sicily (Leonardi et al., 1992).

According to Pérez-Suarez (2009), the strong seasonality in leaf-litterfall recorded in other ecosystems with a variety of deciduous and evergreen species (West, 1985; Berg and Meentemeyer, 2001; Liu et al., 2001) has been attributed to interactive effects of weather patterns (e.g. drought), species phenology (Binkley et al., 1992; Liu et al., 2001; Berg and Meentemeyer, 2001) and the temporal distribution of precipitation events (Liu et al., 2004).

For the decomposition rate, the values observed for Quercus canariensis stand at Khroufa indicate that the decomposition of litter is relatively fast (369 days), which can be explained by the climatic conditions favorable to the decomposers and the biological activity in this stand. On the other hand, it has been found that there is a significant difference with the coefficients found following the decomposition experiment using the litterbag method.

Van Wesemael (1992) studied decomposition in the Mediterranean forests of Italy (Tuscany) by the litterbag method, and found a rate of decomposition respectively equal to $50 \% \mathrm{yr}^{-1}$ and $47 \% \mathrm{yr}^{-1}$ in Quercus cerris and Quercus suber after one year of decomposition.

This difference highlights the critical importance of mesofauna, prevented from acting by using litterbag method (Bernhard, 1970).

The decomposition rate of Quercus canariensis and Quercus suber reached $1.69 \mathrm{yr}^{-1}$ and $1.1 \mathrm{yr}^{-1}$ in Southern Spain (Aponte et al., 2012). Moreover, the decomposition of Quercus serrata is rapid over time. For instance, according to Pandey et al. (2007) the decomposition rate is $2.37 \mathrm{yr}^{-1}$ and the half life time is 107 days.

These high values are due to the climate characterized by an alternation of dry and wet periods which play an essential part in the regulation of decomposition rates (Tripathi and Singh, 1992) by changing microbial communities in the process of organic matter decomposition (Arunachalam et al., 1997).

\section{Conclusion}

The examination of the seasonal variation of litterfall at different oak forests in Tunisia shows that there are no differences between the two study sites of Khroufa and Ain Zena; the only difference is between stands. This could be related to the differences phenological alterations of the species studied. The results suggested that total annual litterfall vary significantly according to forests, with a range of 6.06-9.89 $\mathrm{tha}^{-1} \mathrm{yr}^{-1}$, and that leaf litter is the main component.

In Quercus suber the observed links between leaf fall and climatic variables are as they were be expected in typical Mediterranean forests, in which low rainfall and high temperatures favor leaf fall in spring. As for deciduous species, the opposite is true.

Our results will help develop litterfall models in response to climate change in the future studies. 
In addition, the litterfall is an important phase in the biogeochemical cycle of nutrients that ensure the productivity of ecosystems. The knowledge of the quantities of biomass returning to the soil and the released minerals allow, with other criteria such as decomposition rate, to give an idea about their use by plants and to determine the excesses or deficiencies in a given ecosystem.

\section{REFERENCES}

[1] Aloui, A. (1982): Recherches dendroclimatologiques en kroumirie (Tunisie). - Thèse de Docteur Ingénieur, Fac. St. Jérome, Marseille.

[2] Aponte, C., Garcia, L. V., Teodoro, M. (2012): Tree Species effect on litter decomposition and nutrient release in mediterranean oak forests changes over time. Ecosyst. 15: 1204-1218.

[3] Arunachalam, K., Arunachalam, R. S., Tripathi, H. N., Pandey, H. N. (1997): Dynamics of microbial population during the aggradation phase of a selectively logged subtropical humid forest in north-east India. - Trop. Ecol. 38: 333-341.

[4] Bellot, J., Sánchez, J. R., Lledo, M. J., Martinez, P., Escarré, A. (1992): Litterfall as a measure of primary production in Mediterranean holm-oak forest. - Vegetatio 99-100: 69-76.

[5] Ben Yahia, K., Chaar, H., Bahri, S., Mhamdi, S., Soudani, K., Khouaja, A., Hasnaoui, B. (2016): Phenological monitoring of cork oak in Kroumirie (northwest Tunisia). - Journal of Chemical, Biological and Physical Sciences 6(4): 1258-1281.

[6] Berg, B., Meentemeyer, V. (2001): Litter fall in some European coniferous forests as dependent on climate: a synthesis. - Can. J For. Res. 31: 292-301.

[7] Bernhard, F. (1970): Etude de la litière et de sa contribution au cycle des éléments minéraux en forêt ombrophile de côte-d'Ivoire. - Ecol. Plant 5: 247-266.

[8] Binkley, D., Dunkin, K. A., Debell, D., Ryan, M. G. (1992): Production and nutrient cycling in mixed plantation of Eucalyptus and Albizia in Hawaii. - For. Sci. 38: 393-408.

[9] Bray, J. R., Gorham, E. (1964): Litter production in forests of the world. - Adv. Ecol Res. 2: $101-157$.

[10] Caritat, A., Bertoni, G., Molinas, M., Oliva, M., Dominguez-Planella, A. (1996): Litterfall and mineral return in two cork-oak forests in northeast Spain. - Ann. Sci. For. 53: 1049-1058.

[11] Caritat, A., Garcia, B. E., Lapena, R., Vilar, L. (2006): Litter production in a Quercus suber forest of Montseny (NE Spain) and its relationship to meteorological conditions. Ann. For. Sci. 63: 791-800.

[12] Escudero, A., Del Arco, J. M. (1987): Ecological significance of the phenology of leaf abscission. - Oikos 49: 11-14.

[13] Janssens, I. A., Pilegaard, K. (2003) Large seasonal changes in $\mathrm{Q}_{10}$ of soil respiration in a beech forest. - Global Change Biol. 9: 911-918.

[14] Leonardi, S., Rapp, M., Failla, M., Komaromy, E. (1992): Biomasse, minéralomasse, productivité et gestion de certains éléments biogènes dans une forêt de Quercus suber $L$. en Sicile (Italie). - Ecol. Mediter. 18: 89-98.

[15] Liski, J., Palosuo, T., Peltoniemi, M., Sievanen, R. (2005): Carbon and decomposition model Yasso for forest soils. -Ecol. Model. 189: 168-182.

[16] Liu, C., Wetsman, C. J., Berg, B., Kutsch, W., Wang, G. Z., Man, R., Ilvesniemi, H. (2004): Variation in litterfall-climate relationships between coniferous and broadleaf forest in Eurasia. - Glob. Ecol. Biogeog. 13: 105-114.

[17] Liu, C. J., Wetsman, C. J., Ilvesniemi, H. (2001): Matter and nutrient dynamic of pine (P. cembroides tabulaeformis) and oak (Q. potosina variabilis) litter in North China. - Silva Fen. 35: 3-13. 
[18] Martin, A., Gallardo, J. F., Santa Regina, I. (1996): Aboveground litter production and bioelement potential return in an evergreen oak (Quercus rotundifolia) woodland near Salamanca (Spain). - Ann. Sci. For. 53: 811-818.

[19] Olson, J. S. (1963): Energy storage and the balance of producers and decomposers in ecological Systems. - Ecol. 44: 322-331.

[20] Pandey, R. R., Sharma, G., Tripathi, S. K., Singh, A. K. (2007): Litterfall, litter decomposition and nutrient dynamics in a subtropical natural oak forest and managed plantation in northeastern India. - For. Ecol. Manage. 240: 96-106.

[21] Pérez-Suarez, M., Arredondo-Moreno, J. T., Huber-Sannwald, E., Vargas-Hernadez, J. J. (2009): Production and quality of senesced and green litterfall in a pine-oak forest in central-northwest Mexico. - For. Ecol. Manage. 258: 1307-1315.

[22] Raouane, M. (1985): Dendroclimatological study of the zeen oak of the Western Rif and the Middle Atlas in Morocco. - Ph.D. Thesis, Fac. St. Jerome, Marseille.

[23] Sa, C., Madeira, M., Gazarini, L. (2001): Producao e decomposicao da folhada de Quercus suber L. - Rev. Cie. Agr. 24: 245-256.

[24] Sayer, E. J. (2006): Using experimental manipulation to assess the roles of leaf litter in the functioning of forest ecosystems. - Biol. Rev. 81: 1-31.

[25] Schlesinger, W. H. (1997): Biogeochemistry, an Analysis of Global Change. 2nd ed. Academic Press, New York.

[26] Selmi, M. (1985): Différenciation des sols et fonctionnement des écosystèmes forestiers sur grés numidien de Kroumirie (Tunisie). Ecologie de la subéraie-Zeenaie. - Thèse de Doctorat d'état, Université de Nancy I.

[27] Tripathi, S. K., Singh, K. P. (1992): Abiotic and litter quality control during the decomposition of different plant parts in dry tropical bamboo savanna in India. Pedobiologia 36(4): 109-124.

[28] Van Wesemael, B., Veer, M. A. C. (1992): Soil organic matter accumulation, litter decomposition and humus forms under Mediterranean-type forests in forests in southern Tuscany (Italy). - J. Soil Sci. 43: 133-144.

[29] Vitousek, P., Gerrish, G., Turner, D. R., Walker, L., Mueller-Dombois, D. (1995): Litterfall and nutrient cycling in four Hawaiia Montane rain forest. - J. Trop. Ecol. 11: 189-203.

[30] Vogt, K. A., Grier, C. C., Vogt, D. J. (1986): Production, turnover and nutrient dynamics of above- and below-ground detritus of the world forests. - Adv. Ecol. Res. 15: 303-377.

[31] West, N. E. (1985): Aboveground litter production of three temperate semi desert shrubs. - Amer. Mid. Natur. 113: 158-169. 